\title{
Clinical evaluation of omega-3 fatty acids in psoriasis
}

\section{Kliniczna ocena działania kwasów tłuszczowych omega-3 w leczeniu łuszczycy}

\author{
Mohammad Adil', Pramod Kumar Singh², Kopal Maheshwari²
}

'Department of Dermatology, Jawaharlal Nehru Medical College, A.M.U., Aligarh, India 2Department of Dermatology, Venereology \& Leprosy, S. N. Medical College, Agra, India

'Department of Dermatology, Jawaharlal Nehru Medical College, A.M.U., Aligarh, Indie 2Department of Dermatology, Venereology \& Leprosy, S. N. Medical College, Agra, Indie

\section{CORRESPONDING AUTHOR/} ADRES DO KORESPONDENCJI:

Mohammad Adil MD

Department of Dermatology Jawaharlal Nehru Medical College

A.M.U., Aligarh-202002, India

Phone: +91 8171169131

E-mail: dr.mohd.adil@gmail.com

\begin{abstract}
Introduction. Omega-3 fatty acids are largely derived from fish oils and are known to decrease inflammation. There have been a few small studies showing the beneficial effect of omega-3 fatty acids in psoriasis.

Objective. To evaluate the efficacy of omega-3 fatty acids in conjunction with emollients in patients with mild to moderate chronic plaque psoriasis.
\end{abstract}

Materials and methods. A total of 200 clinically diagnosed cases of chronic plaque psoriasis with less than $10 \%$ of body surface area involvement were recruited and divided into group A and group B. Group A was given 1,800 mg daily of omega-3 fatty acids in three divided oral doses and topical paraffin over the lesions. Group B was prescribed only topical paraffin. At the end of 12 weeks, treatment response was assessed by means of Psoriasis Area Severity Index (PASI), and by its components including area involved, erythema, induration and desquamation scores.

Results. The mean PASI score changed from 7.44 to 3.96 in group A, and from 7.24 to 5.19 in group B. There was a statistically significant difference in PASI, erythema, induration, desquamation scores and area involved between the two groups after 12 weeks. Forty four (46.3\%) patients in group A and $13(13.9 \%)$ patients in group B achieved a 50\% or more reduction in PASI scores.

Conclusions. Omega-3 fatty acids in conjunction with topical emollients appear to reduce the severity of psoriasis with no major side effects. The combination can be a useful adjunct to other psoriasis treatments.

\section{STRESZCZENIE}

Wprowadzenie. Kwasy omega-3 są pozyskiwane głównie z olejów rybnych. Jedną z potwierdzonych właściwości tych kwasów jest hamowanie stanu zapalnego. Przeprowadzono dotychczas kilka niewielkich badań, w których stwierdzono skuteczność kwasów tłuszczowych omega-3 w leczeniu łuszczycy.

Cel pracy. Ocena skuteczności działania kwasów tłuszczowych omega-3 w skojarzeniu z emolientami w leczeniu pacjentów z łuszczycą plackowatą łagodną i umiarkowaną. 
Materiał i metodyka. Do badania włączono 200 pacjentów z klinicznie rozpoznaną łuszczycą obejmującą poniżej $10 \%$ powierzchni skóry. Uczestników podzielono na dwie grupy: A i B. Pacjenci z grupy A przyjmowali doustnie $1800 \mathrm{mg}$ kwasów tłuszczowych omega-3 dziennie $\mathrm{w}$ trzech dawkach podzielonych oraz stosowali parafinę miejscowo na zmiany skórne. Pacjenci z grupy B przyjmowali wyłącznie parafinę. Po upływie 12 tygodni odpowiedź na leczenie oceniono przy wykorzystaniu wskaźnika PASI (Psoriasis Area Severity Index), na podstawie powierzchni skóry objętej zmianami oraz stopnia nasilenia rumienia, nacieku i łuski.

Wyniki. Średni wskaźnik PASI zmniejszył się z 7,44 do 3,96 w grupie A oraz z 7,24 do 5,19 w grupie B. Różnica między grupami pod względem wskaźnika PASI, nasilenia rumienia, nacieku i łuski oraz powierzchni zmian skórnych po upływie 12 tygodni była istotna statystycznie. U 44 $(46,3 \%)$ pacjentów z grupy A i 13 (13,9\%) pacjentów z grupy B stwierdzono co najmniej 50-procentowe obniżenie wskaźnika PASI.

Wnioski. Kwasy tłuszczowe omega-3 w skojarzeniu z miejscowo stosowanymi emolientami zmniejszają nasilenie łuszczycy, nie wywołując poważnych działań niepożądanych. Analizowane skojarzenie może być przydatne jako terapia wspomagająca inne sposoby leczenia łuszczycy.

Key words: psoriasis, omega-3, fish oils.

Słowa kluczowe: łuszczyca, omega-3, oleje rybne.

\section{INTRODUCTION}

Psoriasis is a chronic inflammatory disease characterized classically by sharply demarcated, red indurated plaques over the extensor surfaces of the body and scalp, accompanied by silvery white scales [1]. It has an estimated prevalence ranging from $0.1 \%$ to $11.8 \%$ in various populations, with an average of $2-3 \%$ [2]. It is considered to be an immune mediated inflammatory disease with the accumulation of Th1, Th17 and Th22 lymphocytes in the skin [3]. The levels of the pro-atherogenic proteins: myeloid-related protein 8 (MRP8, S100A8), myeloid-related protein 14 (MRP14, S100A9) and interleukin 6 (IL-6) are increased in psoriasis, predisposing patients to metabolic syndrome [4]. Despite a myriad of treatment modalities for psoriasis, the disease is characterized by remissions and exacerbations seriously impeding the quality of life in patients [5]. Some treatments can only be used for restricted periods of time due to their toxicity or, in some cases, diminution of effects with time is observed. This warrants safer and effective treatment options that may be used as alternatives or adjuncts to conventional treatments. These include lifestyle modifications such as elimination of smoking and alcohol, stress-relieving procedures, exercise and dietary supplementation with omega-3 fatty acids and vitamin D [6].

\section{WPROWADZENIE}

Łuszczyca jest przewlekłą chorobą zapalną, która cechuje się obecnością na powierzchniach wyprostnych kończyn oraz na owłosionej skórze głowy ostro odgraniczonych ognisk naciekowych pokrytych srebrnobiałą łuską [1]. Częstość występowania schorzenia wynosi 0,1-11,8\% w zależności od populacji, przy czym średnia to 2-3\% [2]. Łuszczycę uznaje się za chorobę zapalną o podłożu immunologicznym, w której przebiegu dochodzi do akumulacji limfocytów Th1, Th17 i Th22 w skórze [3]. W łuszczycy obserwuje się również wzrost stężenia białek proaterogennych: białka szpikowo zależnego 8 (MRP8, S100A8), szpikowo zależnego 14 (MRP14, S100A9) oraz interleukiny 6 (IL-6). Zjawisko to predysponuje chorych na łuszczycę do rozwoju zespołu metabolicznego [4]. Pomimo wielu sposobów terapii łuszczycy choroba przebiega z okresami remisji i zaostrzeń, znacząco obniżając jakość życia chorych [5]. Niektóre terapie mogą być stosowane jedynie przez określony czas z powodu ich toksyczności. W części przypadków w czasie leczenia stwierdza się zmniejszenie jego skuteczności. Z tego względu uzasadnione jest poszukiwanie bezpieczniejszych i bardziej skutecznych opcji terapeutycznych, które mogą być alternatywą dla konwencjonalnego leczenia lub terapią wspomagającą. Należy wymienić modyfikacje trybu życia, m.in. rezygnację z palenia tytoniu i spożywania alkoholu, ogra- 
Omega-3 fatty acids include eicosapentaenoic acid (EPA) and docosahexaenoic acid (DHA), and are chiefly obtained from marine fish and algae [7]. They have been shown to reduce symptoms in several inflammatory diseases. Eicosapentaenoic acid metabolizes through the same metabolic pathway as arachidonic acid (AA) and its hydroxylated metabolites form leukotriene (LT) B5, a metabolite which is ten times less chemotactic for neutrophils than LTB4 produced from AA and also a less potent keratinocyte proliferation stimulator [8]. Hence, the production of AA and its proinflammatory by-products like LTB4, C4 etc. is competitively inhibited. Furthermore, omega- 3 fatty acids act on the endothelial cells directly and indirectly. They decrease the production of tumour necrosis factor $\alpha$ (TNF- $\alpha$ ), IL-1 and platelet derived growth factor, and increase nitric oxide production. All these changes prevent vascular proliferation in the developing psoriatic plaque [6]. Emollients are substances that form an occlusive barrier on the stratum corneum and have anti-inflammatory properties. They are helpful for reducing scaling, itching and inflammation, and represent the first line of therapy in patients with psoriasis [9].

There have been several small studies evaluating the role of omega-3 fatty acid supplementation in psoriasis patients. Most of them have found omega-3 fatty acids to be beneficial [10-18].

\section{OBJECTIVE}

This study was performed to evaluate the effects of oral intake of omega-3 fatty acids with topical emollient therapy in patients with mild to moderate psoriasis.

\section{MATERIALS AND METHODS}

This was a prospective, open, observational study conducted in an outpatient department of dermatology between March 2013 and March 2015. Ethical clearance was obtained from the institutional review board. A total of 200 clinically diagnosed cases of chronic plaque psoriasis of mild to moderate severity ( $<10 \%$ body surface area involved) [19] attending the outpatient department were selected for the study and divided into two groups of 100 cases each (group A and group B). Psoriasis Area Severity Index (PASI) was used as the primary outcome measure to power the study. Sample size was calculated setting the level of significance at $5 \%$ and the power of study at $80 \%$. An estimated decrease of PASI of 3.5 in group A and 2.5 in group $\mathrm{B}$ and a standard deviation of 2.5 were considered niczenie stresu, zwiększenie aktywności fizycznej oraz suplementację kwasami tłuszczowymi omega-3 i witaminą D [6].

Do kwasów tłuszczowych omega-3 należą m.in. kwas eikozapentaenowy (EPA) i kwas dokozaheksaenowy (DHA). Pozyskuje się je głównie z ryb morskich i glonów [7]. Potwierdzono ich skuteczność w łagodzeniu objawów niektórych chorób zapalnych. Kwas eikozapentaenowy jest metabolizowany w obrębie tego samego szlaku metabolicznego co kwas arachidonowy (AA), a jego hydroksylowane metabolity tworzą leukotrien (LT) B5. Jest to metabolit, który cechuje się 10-krotnie słabszymi właściwościami chemotaktycznymi w stosunku do neutrofilów niż leukotrien LTB4 wytwarzany z AA, a także słabszym działaniem stymulującym proliferację keratynocytów [8]. Dzięki temu konkurencyjnemu hamowaniu wytwarzany jest AA i jego prozapalne produkty uboczne (LTB4, C4 itp.). Kwasy omega-3 oddziałują bezpośrednio i pośrednio na komórki śródbłonka. Zmniejszają wytwarzanie czynnika martwicy nowotworów $\alpha$ (TNF- $\alpha$ ), IL-1 i płytkopochodnego czynnika wzrostu oraz nasilają wytwarzanie tlenku azotu. Wszystkie te zmiany zapobiegają proliferacji naczyniowej w rozwijających się wykwitach łuszczycowych [6]. Emolienty są substancjami, które tworzą barierę okluzyjną w warstwie rogowej naskórka i mają właściwości przeciwzapalne. Przyczyniają się do ograniczenia łuszczenia, świądu skóry i stanu zapalnego. Stosuje się je jako leczenie pierwszego rzutu u chorych na łuszczycę [9].

Przeprowadzono kilka niewielkich badań oceniających przydatność suplementacji kwasami omega-3 w terapii łuszczycy. Większość z nich potwierdziła korzystny wpływ kwasów omega-3 u pacjentów z łuszczycą [10-18].

\section{CEL PRACY}

Celem badania była ocena skuteczności działania przyjmowanych doustnie kwasów omega-3 w skojarzeniu z miejscowo stosowanymi emolientami w leczeniu pacjentów z łuszczycą o nasileniu łagodnym do umiarkowanego.

\section{MATERIA I I METODYKA}

Prospektywne, otwarte badanie obserwacyjne przeprowadzono u pacjentów poradni dermatologicznej od marca 2013 do marca 2015 r. Uzyskano zgodę komisji bioetycznej. Do badania włączono ogółem 200 pacjentów z łuszczycą plackowatą o nasileniu łagodnym do umiarkowanego (zmiany skórne $<10 \%$ powierzchni ciała) [19] leczonych w poradni dermatologicznej. Uczestników podzielono na dwie grupy (A i B), każda po 100 pacjentów. Za główny punkt końcowy badania przyjęto wskaźnik nasilenia łuszczy- 
for this purpose. Exclusions from the study included subjects younger than 15 or older than 50 years of age, pregnant and lactating women, patients with bleeding disorders, history of stroke or diabetes mellitus, or with secondarily infected lesions. Patients who had received phototherapy or some form of systemic immunotherapy were included in the study after a washout period of 4 weeks. After obtaining informed consent from the patients, data was collected regarding their age, sex, duration of disease, age at onset and prior treatment. Also, clinical photographs were taken for future comparison. Group A subjects were prescribed a daily dose of 6 fish oil capsules, each containing $300 \mathrm{mg}$ of EPA and DHA, in three divided doses (a total of $1.8 \mathrm{~g}$ of omega-3 fatty acids a day). The treatment was continued for 3 months. The patients were also advised to apply paraffin to the skin once a day. Antihistamines were prescribed as per need. Group B patients were instructed to use only topical paraffin therapy and antihistamines for 3 months. The patients were followed up every month. Any adverse effects of the therapy in the two groups were also recorded.

The outcome was measured using the PASI score, and individual PASI components including area involved, erythema, scaling and induration scores. PASI is a five-point scoring system that has become the gold standard in the assessment of the severity of psoriasis in clinical trials [20]. A reduction in PASI by $75 \%$ or even $50 \%$ is considered clinically significant [21]. Relevant data was collected, tabulated and analyzed with respect to the mean, standard deviation and percentage.

\section{Statistical analysis}

Significant conclusions were drawn using statistical tests of significance $\left(\chi^{2}\right.$ test and paired and unpaired $t$ tests) by means of SPSS software version 16.0 .

\section{RESULTS}

A total of 100 patients were recruited for each study group. The baseline characteristics of the patients are given in Table 1. Group A consisted of 61 men and 39 women, and group B: 65 men and 35 women. The mean age of the patients in group A was 35.99 years with a standard deviation of 9.70 years. The patients in group B had a mean age of 36.81 years at presentation, with a standard deviation of 9.26 years. There were no statistical differences between the patients in the two groups in terms of age or sex at the baseline. The mean duration of the disease in group A was 7.18 years cy Psoriasis Area Severity Index (PASI). Wielkość próby obliczono, ustalając $5 \%$ jako poziom istotności oraz $80 \%$ jako moc statystyczną badania. W tym celu założono, że szacowane obniżenie wskaźnika PASI wyniesie $3,5 \mathrm{w}$ grupie A i $2,5 \mathrm{w}$ grupie $B$, a odchylenie standardowe 2,5. Z badania wyłączono uczestników w wieku poniżej 15 i powyżej 50 lat, kobiety w ciąży oraz w okresie karmienia piersią, a także pacjentów z zaburzeniami krzepnięcia, udarem lub cukrzycą w wywiadzie oraz obecnością wtórnie zakażonych zmian. Pacjentów poddawanych fototerapii lub leczonych jednym ze schematów ogólnoustrojowej immunoterapii włączono do badania po 4 tygodniach całkowitej eliminacji leku z organizmu. Po uzyskaniu od pacjentów świadomej zgody na udział w badaniu zgromadzono dane obejmujące wiek, płeć, czas trwania choroby, wiek zachorowania i wiek przed podjęciem leczenia. Wykonano również fotografie obrazujące stan kliniczny do celów porównawczych. Pacjentom z grupy A zalecono przyjmowanie 6 kapsułek zawierających olej rybny dziennie, w 3 dawkach podzielonych. Każda z kapsułek zawierała 300 mg EPA i DHA. Łączna dobowa dawka kwasów omega-3 wynosiła 1,8 g. Leczenie kontynuowano przez 3 miesiące. Pacjentom z tej grupy zalecono aplikację parafiny miejscowo na skórę raz na dobę. Zezwolono na doraźne przyjmowanie leków przeciwhistaminowych. Pacjenci z grupy B stosowali wyłącznie parafinę miejscowo na skórę oraz leki przeciwhistaminowe przez 3 miesiące. Raz w miesiącu przeprowadzano badanie kontrolne. Obie grupy badano pod kątem działań niepożądanych związanych z leczeniem.

Wynik leczenia oceniano na podstawie wskaźnika PASI oraz jego poszczególnych składników: powierzchni zajętej przez zmiany skórne, nasilenia rumienia, łuski i nacieku. Komponenty PASI ocenia się w 5-punktowej skali. Wskaźnik PASI stosuje się aktualnie jako złoty standard w ocenie stopnia nasilenia łuszczycy w badaniach klinicznych [20]. Obniżenie PASI o 75\%, a nawet o 50\% uznaje się za klinicznie istotne [21]. Zgromadzone dane przedstawiono tabelarycznie oraz wyliczono wartości średnie, odchylenie standardowe i wskaźnik procentowy.

\section{Analiza statystyczna}

Wnioski o istotności oparto na wynikach statystycznych testów istotności (testu $\chi^{2}$ oraz testu $t$-Studenta dla danych sparowanych i niesparowanych) przy wykorzystaniu oprogramowania SPSS wersja 16.0.

\section{WYNIKI}

Do każdej z badanych grup włączono 100 pacjentów. Charakterystykę wyjściową pacjentów przedstawiono w tabeli 1. Grupa A obejmowała 61 mężczyzn i 39 kobiet, a grupa B - 65 mężczyzn i 35 kobiet. Średni wiek pacjentów w grupie A wynosił 35,99 roku z od- 
Table I. Baseline characteristics of the patients

Tabela I. Charakterystyka myjściowa pacjentów

\begin{tabular}{lcccc} 
Baseline characteristics/ & $\begin{array}{c}\text { Total/Ogółem } \\
(n=200)\end{array}$ & $\begin{array}{c}\text { Group A/Grupa A } \\
(n=100)\end{array}$ & $\begin{array}{c}\text { Group B/Grupa B } \\
(n=100)\end{array}$ & $\begin{array}{c}P \text {-value/ } \\
\text { Wartość } p\end{array}$ \\
$\begin{array}{l}\text { Sex (male/female)/płeć (mężczyźni/kobiety) } \\
\text { Mean age/średni wiek }\end{array}$ & $36.24 \pm 9.47$ & $35.99 \pm 9.70$ & $36.81 \pm 9.26$ & 0.5580 \\
\hline Duration/czas trwania choroby & $7.01 \pm 6.20$ & $7.18 \pm 6.74$ & $6.83 \pm 5.67$ & 0.6915 \\
\hline Drop-outs/uczestnicy, którzy nie ukończyli badania & 12 & 5 & 7 & 0.5515 \\
\hline
\end{tabular}

Table 2. Disease severity scores at baseline

Tabela 2. Wyjściowy stopień nasilenia choroby

\begin{tabular}{|c|c|c|c|c|}
\hline $\begin{array}{l}\text { Mean severity scores/ } \\
\text { Średnie nasilenie choroby }\end{array}$ & $\begin{array}{c}\text { Group A/Grupa A } \\
(n=95) \\
\text { Mean } \pm \text { SD/Średnia } \pm \text { SD } \\
(95 \% \mathrm{Cl})\end{array}$ & $\begin{array}{c}\text { Group B/Grupa B }(n=93) \\
\text { Mean } \pm \text { SD/Średnia } \pm \text { SD } \\
(95 \% \mathrm{Cl})\end{array}$ & $\begin{array}{c}\text { Difference between } \\
\text { groups/Różnica między } \\
\text { grupami } \\
\text { Mean/Średnia }(95 \% \mathrm{Cl})\end{array}$ & $\begin{array}{c}\text { P-value/ } \\
\text { Wartość } P\end{array}$ \\
\hline $\begin{array}{l}\text { Mean PASI score/ } \\
\text { średni wskaźnik PASI }\end{array}$ & $\begin{array}{l}7.44 \pm 2.84 \\
(6.87,8.01)\end{array}$ & $\begin{array}{l}7.24 \pm 2.99 \\
(6.63,7.85)\end{array}$ & $\begin{array}{c}-0.20 \pm 0.42 \\
(1.04,0.64)\end{array}$ & 0.6387 \\
\hline $\begin{array}{l}\text { Mean erythema score/ } \\
\text { średnie nasilenie rumienia }\end{array}$ & $\begin{array}{l}2.50 \pm 1.15 \\
(2.27,2.73)\end{array}$ & $\begin{array}{l}2.34 \pm 1.06 \\
(2.12,2.56)\end{array}$ & $\begin{array}{l}-0.16 \pm 0.16 \\
(-0.48,0.16)\end{array}$ & 0.3228 \\
\hline $\begin{array}{l}\text { Mean induration score/ } \\
\text { średnie nasilenie nacieku }\end{array}$ & $\begin{array}{l}2.39 \pm 1.22 \\
(2.14,2.64) \\
\end{array}$ & $\begin{array}{l}2.31 \pm 1.20 \\
(2.07,2.55) \\
\end{array}$ & $\begin{array}{l}-0.08 \pm 0.18 \\
(-0.43,0.27)\end{array}$ & 0.6509 \\
\hline $\begin{array}{l}\text { Mean desquamation score/ } \\
\text { średnie nasilenie łuski }\end{array}$ & $\begin{array}{l}2.54 \pm 1.10 \\
(2.32,2.76) \\
\end{array}$ & $\begin{array}{l}2.59 \pm 1.13 \\
(2.36,2.82) \\
\end{array}$ & $\begin{array}{c}0.05 \pm 0.16 \\
(-0.27,0.37) \\
\end{array}$ & 0.7589 \\
\hline $\begin{array}{l}\text { Mean area involved/średnia } \\
\text { powierzchnia zmian skórnych }\end{array}$ & $\begin{array}{l}6.04 \pm 2.03 \\
(5.63,6.45)\end{array}$ & $\begin{array}{l}5.96 \pm 1.98 \\
(5.56,6.36)\end{array}$ & $\begin{array}{l}-0.08 \pm 0.29 \\
(-0.66,0.50)\end{array}$ & 0.7848 \\
\hline
\end{tabular}

with a standard deviation of 6.74 years, and in group B it was 6.83 years with a standard deviation of 5.67 years. This difference was also found to be statistically insignificant. A total of 5 patients dropped out of group A and 7 out of group B before the end of the study. Consequently, 95 patients from group A and 93 patients from group B completed the study.

Table 2 shows the baseline severity scores of the patients remaining after the dropout. PASI score at baseline was 7.44 with a standard deviation of 2.84 for group A, and $7.24 \pm 2.99$ for group B. The difference between the two was statistically insignificant. The difference in the mean erythema scores, mean induration scores, mean desquamation scores and mean area scores between the two groups was statistically insignificant at the baseline.

The severity scores at the end of the therapy at 12 weeks are summarized in Table 3 . After 12 weeks mean PASI scores were $3.96 \pm 2.52$ and $5.19 \pm 2.48$ in group A and group B, respectively. The change in PASI in both groups when compared to the baseline was significant. The difference in PASI between the two groups at 12 weeks was also statistically significant. A total of $44(46.3 \%)$ patients achieved the PASI score of 50 (50\% reduction) in group A. The number in group B was $13(13.9 \%)$. We also observed statistically signifi- chyleniem standardowym 9,70 roku. Średni wiek badanych w grupie B wynosił 36,81 roku przy rozpoznaniu, a odchylenie standardowe 9,26 roku. Nie stwierdzono różnic statystycznych pomiędzy pacjentami w obu grupach pod względem wyjściowego wieku i płci. Średni czas trwania choroby w grupie A wynosił 7,18 roku (odchylenie standardowe: 6,74 roku), a w grupie B - 6,83 roku (odchylenie standardowe: 5,67 roku). Wykazano, że ta różnica nie jest statystycznie istotna. Badania nie ukończyło 5 pacjentów z grupy A oraz 7 z grupy B. Tym samym badanie ukończyło 95 pacjentów z grupy A i 93 pacjentów z grupy B.

Dane przedstawiające wyjściowy stopień nasilenia choroby u pacjentów, którzy ukończyli badanie, przedstawiono w tabeli 2. Wyjściowy wskaźnik PASI wyniósł 7,44 (odchylenie standardowe: 2,84 ) w grupie A oraz $7,24 \pm 2,99$ w grupie B. Różnica między tymi wartościami nie była statystycznie istotna. Różnica pomiędzy grupami w zakresie średniego nasilenia rumienia, nacieku i łuski oraz średniej powierzchni zmian skórnych na początku badania była statystycznie nieistotna.

Wyniki nasilenia choroby po 12 tygodniach leczenia przedstawiono w tabeli 3. Po 12 tygodniach średni wskaźnik PASI kształtował się na poziomie 3,96 $\pm 2,52$ i 5,19 $\pm 2,48$, odpowiednio w grupach A i B. Zmiana PASI w obu grupach w stosunku do wyjściowego poziomu była statystycznie istotna. Istotność statystyczną wykazano również 
Table 3. Severity scores at the end of 12 weeks

Tabela 3. Stopień nasilenia choroby po upływie 12 tygodni

\begin{tabular}{|c|c|c|c|c|c|c|}
\hline \multirow{2}{*}{$\begin{array}{l}\text { Mean severity } \\
\text { scores/Średnie } \\
\text { nasilenie choroby }\end{array}$} & \multicolumn{2}{|c|}{$\begin{array}{c}\text { Group A/Grupa A } \\
\qquad(n=95)\end{array}$} & \multicolumn{2}{|c|}{$\begin{array}{l}\text { Group B/Grupa B } \\
\qquad(n=93)\end{array}$} & \multirow{2}{*}{$\begin{array}{l}\text { Difference between } \\
\text { groups/Różnica } \\
\text { między grupami } \\
\text { Mean } \pm \text { SD/ } \\
\text { Średnia } \pm \text { SD } \\
(95 \% \mathrm{Cl})\end{array}$} & \multirow[t]{2}{*}{$\begin{array}{c}\text { P-value/ } \\
\text { Wartość } p\end{array}$} \\
\hline & $\begin{array}{c}\text { Actual } \\
\text { calculated value/ } \\
\text { Rzeczywista } \\
\text { obliczona } \\
\text { wartość } \\
\text { Mean } \pm \text { SD/ } \\
\text { Średnia } \pm \text { SD } \\
(95 \% \mathrm{Cl})\end{array}$ & $\begin{array}{c}\text { Decrease } \\
\text { from baseline/ } \\
\text { Zmniejszenie } \\
\text { w stosunku } \\
\text { do wartości } \\
\text { wyjściowej } \\
\text { Mean } \pm \text { SD/ } \\
\text { Średnia } \pm \text { SD } \\
(95 \% \mathrm{Cl})\end{array}$ & $\begin{array}{c}\text { Actual } \\
\text { calculated value/ } \\
\text { Rzeczywista } \\
\text { obliczona } \\
\text { wartość } \\
\text { Mean } \pm \mathrm{SD} / \\
\text { Średnia } \pm \mathrm{SD} \\
(95 \% \mathrm{Cl})\end{array}$ & $\begin{array}{c}\text { Decrease } \\
\text { from baseline/ } \\
\text { Zmniejszenie } \\
\text { w stosunku } \\
\text { do wartości } \\
\text { wyjściowej } \\
\text { Mean } \pm \mathrm{SD} / \\
\text { Średnia } \pm \mathrm{SD} \\
(95 \% \mathrm{Cl})\end{array}$ & & \\
\hline $\begin{array}{l}\text { Mean PASI score/ } \\
\text { średni wskaźnik PASI }\end{array}$ & $\begin{array}{l}3.96 \pm 2.52 \\
(3.45,4.47)\end{array}$ & $\begin{array}{l}3.48 \pm 2.18 \\
(3.04,3.91)\end{array}$ & $\begin{array}{l}5.19 \pm 2.48 \\
(4.69,5.69)\end{array}$ & $\begin{array}{l}2.05 \pm 1.77 \\
(1.69,2.41)\end{array}$ & $\begin{array}{l}1.23 \pm 0.37 \\
(0.51,1.95)\end{array}$ & 0.0009 \\
\hline $\begin{array}{l}\text { Mean erythema } \\
\text { score/średnie } \\
\text { nasilenie rumienia }\end{array}$ & $\begin{array}{l}1.19 \pm 0.77 \\
(1.04,1.34)\end{array}$ & $\begin{array}{l}1.31 \pm 0.96 \\
(1.12,1.50)\end{array}$ & $\begin{array}{l}1.63 \pm 0.77 \\
(1.47,1.79)\end{array}$ & $\begin{array}{l}0.72 \pm 0.74 \\
(0.57,0.87)\end{array}$ & $\begin{array}{l}0.44 \pm 0.11 \\
(0.22,0.66)\end{array}$ & 0.0001 \\
\hline $\begin{array}{l}\text { Mean induration } \\
\text { score/średnie } \\
\text { nasilenie nacieku }\end{array}$ & $\begin{array}{l}1.48 \pm 0.98 \\
(1.28,1.68)\end{array}$ & $\begin{array}{l}0.92 \pm 0.81 \\
(0.76,1.08)\end{array}$ & $\begin{array}{l}1.81 \pm 1.03 \\
(1.60,2.01)\end{array}$ & $\begin{array}{l}0.50 \pm 0.71 \\
(0.36,0.64)\end{array}$ & $\begin{array}{l}0.33 \pm 0.15 \\
(0.04,0.62)\end{array}$ & 0.0256 \\
\hline $\begin{array}{l}\text { Mean desquama- } \\
\text { tion score/średnie } \\
\text { nasilenie łuski }\end{array}$ & $\begin{array}{l}1.29 \pm 0.95 \\
(1.10,1.48)\end{array}$ & $\begin{array}{l}1.23 \pm 0.89 \\
(1.05,1.41)\end{array}$ & $\begin{array}{l}1.76 \pm 0.86 \\
(1.58,1.93)\end{array}$ & $\begin{array}{l}0.83 \pm 0.78 \\
(0.67,0.99)\end{array}$ & $\begin{array}{l}0.47 \pm 0.13 \\
(0.21,0.73)\end{array}$ & 0.0005 \\
\hline $\begin{array}{l}\text { Mean area } \\
\text { involved/średnia } \\
\text { powierzchnia zmian } \\
\text { skórnych }\end{array}$ & $\begin{array}{l}4.48 \pm 2.04 \\
(4.07,4.87)\end{array}$ & $\begin{array}{l}1.56 \pm 1.42 \\
(1.27,1.84)\end{array}$ & $\begin{array}{l}5.24 \pm 2.14 \\
(4.80,5.67)\end{array}$ & $\begin{array}{l}0.72 \pm 0.90 \\
(0.54,0.90)\end{array}$ & $\begin{array}{l}0.76 \pm 0.30 \\
(0.16,1.36)\end{array}$ & 0.0135 \\
\hline
\end{tabular}

cant differences in the mean erythema scores, mean induration scores, mean desquamation scores and the area scores in the two groups at the end of the study at 12 weeks.

A total of 11 patients experienced side effects of treatment during the study. Of these, half of the patients developed fishy odour in eructation, and 1 patient reported abdominal discomfort. The patients affected were from group $\mathrm{A}$, and the side effects are attributable to fish oils. Three patients from group B and 1 patient from group A developed folliculitis as a side effect of emollient application. Another patient from group B developed contact dermatitis to the topical treatment. No serious adverse effects of the treatment such as coagulopathy or hypervitaminosis were seen.

\section{DISCUSSION}

Out of a total of 200 patients with psoriasis included in the study, $126(63 \%)$ were male and 74 $(37 \%)$ were female. The Western literature suggests that psoriasis affects both sexes with equal frequency [22]. However, studies from India have pointed to a male preponderance among patients [23]. The male predominance has been explained by Mabuchi et al. to be due to the effect of environmental dla różnicy we wskaźniku PASI pomiędzy grupami po 12 tygodniach. U 44 (46,3\%) pacjentów z grupy A PASI wyniósł 50 (redukcja o 50\%). W grupie B podobną wartość PASI stwierdzono u $13(13,9 \%)$ pacjentów. Odnotowano ponadto statystycznie istotne różnice w zakresie średniego nasilenia rumienia, nacieku i łuski oraz średniej powierzchni zmian skórnych w obu grupach po zakończeniu badania (w 12. tygodniu).

U 11 pacjentów wystąpiły działania niepożądane podczas badania - u połowy odbijanie z nieprzyjemnym rybnym zapachem, a u 1 pacjenta dyskomfort w jamie brzusznej. Dolegliwości te obserwowano wyłącznie w grupie A i były one związane z przyjmowaniem olejów rybnych. U 3 pacjentów z grupy $B$ oraz $\mathrm{u} 1$ pacjenta $\mathrm{z}$ grupy A stwierdzono zapalenie mieszków włosowych jako działanie niepożądane emolientu. U innego pacjenta $\mathrm{z}$ grupy B wystąpiło kontaktowe zapalenie skóry $\mathrm{w}$ reakcji na leczenie miejscowe. Nie odnotowano ciężkich działań niepożądanych, np. koagulopatii czy hiperwitaminozy.

\section{OMÓWIENIE}

W grupie 200 włączonych do badania pacjentów z łuszczycą było 126 (63\%) mężczyzn i 74 (37\%) kobiety. Dane z literatury światowej wskazują, że łuszczyca 
risk factors which are common in men such as smoking, alcohol intake and diet [24]. The mean age of presentation of the patients was $36.24 \pm 9.47$. This finding is consistent with other studies showing the mean age of presentation to be in the mid-thirties $[23,25]$. The mean duration of the disease in our patients was $7.01 \pm 6.20$ years. Arican et al. have observed the mean duration of disease to be 9.3 years [26]. Other studies indicate that most patients have the disease of less than 5 years' duration at the time of presentation [25].

PASI score at baseline for group A was found to be $7.44 \pm 2.84$, and for group B it was $7.24 \pm 2.99$. After 12 weeks of treatment, mean PASI score was $3.96 \pm 2.52$ for group A and $5.19 \pm 2.48$ for group B. This change, as well as the difference in the two groups, was statistically significant. These findings are supported by the report of Balbas et al., who divided 30 patients with stable mild to moderate psoriasis (body surface area involvement of less than $10 \%$ ) into two groups in an open, single centre, controlled observational study. They found a significant difference in the response shown by the group of patients treated with tacalcitol ointment along with $640 \mathrm{mg}$ of omega-3 fatty acids compared to another group treated with tacalcitol ointment only [18]. Similar results were observed by Lassus et al. in an open trial conducted in patients with chronic plaque psoriasis treated with $1.9 \mathrm{~g}$ of omega-3 fatty acids [27]. PASI 50 was achieved by $46.3 \%$ of patients in group A and $13.9 \%$ of patients in group B. The authors observed that $16.25 \%$ of patients showed a $75 \%$ reduction in PASI score after omega-3 fatty acid supplementation, while $84.75 \%$ of patients had a moderate improvement in their PASI scores [27]. Mayser et al. observed that $37 \%$ of patients achieved significant improvement in PASI scores in a double blinded trial evaluating the efficacy of intravenous omega-3 fatty acid infusions [15].

We observed statistically significant changes between group A and B in mean erythema, induration and desquamation scores as well as area scores. This is in line with the study done by Balbas et al. who found that a two-month treatment with omega-3 fatty acids in conjunction with tacrolimus changed the erythema score from 2.93 to 1.13 , the induration score from 2.47 to 0.47 , and the scaling score from 2.27 to 0.13 in the tacrolimus plus omega-3 fatty acid treated group, which was significantly lower than the change in the group treated with tacrolimus alone [18]. Bittner et al. found a significant decrease in erythema and induration but no reduction in scaling following omega- 3 fatty acid supplementation [28]. Gupta et al. also found an improvement in erythema, scaling and area invo- występuje u obu płci z jednakową częstością [22]. Wyniki badań przeprowadzonych w Indiach wykazują przewagę mężczyzn wśród chorych [23]. Prawidłowość tę powiązano w pracy Mabuchi i wsp. z oddziaływaniem czynników środowiskowych dotyczących głównie mężczyzn, takich jak palenie tytoniu, spożycie alkoholu i sposób odżywiania [24]. Średni wiek pacjentów przy rozpoznaniu choroby wynosił 36,24 \$9,47 roku. Wartości te są zgodne $\mathrm{z}$ innymi badaniami, w których podano, że średni wiek przy rozpoznaniu wynosi ok. 35 lat [23, 25]. Średni czas trwania choroby u badanych pacjentów wyniósł 7,01 $\pm 6,20$ roku. W pracy Arican i wsp. średni czas trwania choroby określono jako 9,3 roku [26]. W innych pracach podaje się, że u większości pacjentów choroba trwa krócej niż 5 lat w chwili rozpoznania [25].

Wyjściowy wskaźnik PASI w grupie A wynosił 7,44 $\pm 2,84$, a w grupie B 7,24 $\pm 2,99$. Po 12 tygodniach leczenia średnia wartość PASI zmniejszyła się do 3,96 $\pm 2,52$ w grupie A i 5,19 $\pm 2,48$ w grupie B. Powyższa zmiana, podobnie jak różnica między grupami, była istotna statystycznie. Wyniki te są spójne z pracą Balbas i wsp., którzy w ramach otwartego, jednoośrodkowego, kontrolowanego badania obserwacyjnego podzielili 30 pacjentów ze stabilną łuszczycą o nasileniu łagodnym do umiarkowanego (zmiany skórne $<10 \%$ powierzchni ciała) na dwie podgrupy. Autorzy stwierdzili istotną różnicę $\mathrm{w}$ odpowiedzi na leczenie między podgrupą pacjentów, którzy stosowali takalcytol w postaci maści i 640 mg kwasów omega-3, a podgrupą leczoną wyłącznie maścią zawierającą takalcytol [18]. Podobne wyniki odnotowali Lassus i wsp. w otwartym badaniu przeprowadzonym u pacjentów z przewlekłą łuszczycą pospolitą, którzy przyjmowali 1,9 g kwasów omega-3 [27]. PASI 50 uzyskano u 46,3\% pacjentów w grupie A i 13,9\% pacjentów w grupie B. U 16,25\% pacjentów autorzy zaobserwowali obniżenie PASI o 75\% wskutek suplementacji kwasami omega-3, a u 84,75\% - umiarkowaną poprawę wskaźnika PASI [27]. W badaniu z podwójnie ślepą próbą oceniającym skuteczność kwasów omega-3 w postaci wlewów Mayser i wsp. stwierdzili istotną poprawę wskaźnika PASI u 37\% pacjentów [15].

W naszym badaniu zaobserwowano statystycznie istotne różnice między grupą A a grupą B w zakresie średniego nasilenia rumienia, nacieku i łuski oraz powierzchni zmian skórnych. Są to wyniki spójne z badaniem Balbas i wsp., którzy stwierdzili, że 2-miesięczne leczenie kwasami omega-3 w skojarzeniu z takrolimusem zmniejszyło nasilenie rumienia $\mathrm{z} 2,93$ do 1,13 , nacieku z 2,47 do 0,47 oraz łuski z 2,27 do 0,13. Wyniki pacjentów leczonych takrolimusem w skojarzeniu z kwasami omega-3 były istotnie niższe niż zmiana $\mathrm{w}$ grupie leczonej takrolimusem w monoterapii [18]. Bittner i wsp. uzyskali istotne zmniejszenie nasilenia rumienia i nacieku, jednak nie odnotowali zmian w nasileniu łuski wskutek suplementacji kwasami omega-3 [28]. W badaniu Gupta i wsp. również osiągnięto 
lved in patients treated with narrow-band ultraviolet therapy with fish oils, and observed that the effect persisted even after the light therapy was discontinued and fish oils were given [29]. Kragballe and Fogh observed a clear improvement in body surface area involvement with $9 \mathrm{~g}$ of daily omega-3 fatty acids for 4 months, though they noted that the improvement in erythema and scaling was not significant [30]. Lassus found that $1.9 \mathrm{~g}$ of omega-3 fatty acids produced an improvement in scaling and induration, however erythema persisted [27]. There are several studies showing improvement in different parameters of psoriasis with different doses of omega-3 fatty acids [31]. However other studies showed only slight improvement in patients taking omega-3 fatty acids in comparison to those taking omega- 6 fatty acids [32, 33]. Intravenous infusions of fish oils have been shown to decrease erythema, scaling and induration in patients in a few studies $[14,15]$. Topical fish oil application has been found to be efficacious in a few trials, such as that conducted by Escobar et al. [12], but no improvement over placebo was seen in a double-blind placebo-controlled study [34]. The safety of omega-3 fatty acids is well established and no serious side effects have been found in any studies. Fishy odour and minor gastrointestinal upset are the only side effects reported in these studies $[18,29]$.

Our study had an open non-blinded design which was prone to bias, as the patients were aware of the treatment they were undergoing. The use of PASI in the study is a physician-dependent outcome measure that looks objectively for disease signs. A patient-dependent marker for disease improvement was not used. Also, the study only measured the effect of omega-3 fatty acid on patients with less than $10 \%$ body surface area involved, while patients with severe involvement were excluded from the scope of the study.

\section{CONCLUSIONS}

A treatment that includes daily emollients and oral supplementation of omega-3 fatty acids seems to reduce the severity of chronic plaque psoriasis in most patients. In addition, it is largely free of side effects. Patients with psoriasis show decreases in PASI, erythema, induration and scaling and area scores following such therapy. Being mostly free of side effects and interactions, the treatment appears to be a good adjuvant therapy for psoriasis. It is likely to reduce the dosing, duration and consequently the side effects of conventional treatments for chronic plaque psoriasis. Further studies are needed to establish the optimal dose of omega-3 fatty zmniejszenie nasilenia rumienia, łuski oraz powierzchni zmian skórnych u chorych leczonych naświetleniami wąskopasmowym UV w skojarzeniu z olejami rybnymi. Efekt ten utrzymywał się także po przerwaniu fototerapii i stosowaniu wyłącznie olejów rybnych [29]. Zdecydowaną poprawę stanu pacjentów w zakresie powierzchni zmian skórnych zaobserwowali Kragballe i Fogh u pacjentów przyjmujących 9 g kwasów omega-3 na dobę przez 4 miesiące, jednak poprawa w zakresie nasilenia rumienia i łuski nie była istotna [30]. W badaniu Lassusa wykazano, że kwasy omega-3 w dawce 1,9 $\mathrm{g}$ zmniejszają nasilenie łuski i nacieku, jednak nie powodują zmian w zakresie rumienia [27]. Opublikowano kilka badań, w których potwierdzono poprawę parametrów nasilenia zmian łuszczycowych dzięki stosowaniu kwasów omega-3 w różnych dawkach [31]. W innych badaniach wykazano z kolei jedynie nieznaczną poprawę u pacjentów przyjmujących kwasy omega-3 w porównaniu z kwasami omega-6 [32, 33]. W kilku badaniach stwierdzono, że dożylne wlewy olejów rybnych ograniczają rumień, łuskę i naciek [14, 15]. Istnieją też prace potwierdzające skuteczność olejów rybnych stosowanych miejscowo na skórę. Jedno z takich badań, z podwójnie ślepą próbą i grupą kontrolną placebo, przeprowadzili Escobar i wsp. [12], jednak nie uzyskali poprawy w stosunku do placebo [34]. Bezpieczeństwo stosowania kwasów omega-3 jest powszechnie uznane i w żadnym z badań nie stwierdzono ciężkich działań niepożądanych. Jedynymi działaniami niepożądanymi odnotowanymi w badaniach były rybi zapach oraz nieznaczne dolegliwości żołądkowo-jelitowe [18, 29].

Badanie przedstawione $\mathrm{w}$ niniejszej pracy miało schemat otwarty, bez zaślepienia. Oznacza to podatność na błąd systematyczny, ponieważ pacjenci są świadomi tego, jakie stosują leczenie. Wskaźnik PASI wykorzystany w badaniu stanowi punkt końcowy oceniany przez lekarza, który obiektywnie analizuje objawy choroby. W badaniu nie uwzględniono wskaźnika poprawy ocenianego przez pacjentów. Ponadto $w$ ramach badania analizowano wyłącznie wpływ kwasów omega-3 u pacjentów ze zmianami obejmującymi poniżej $10 \%$ powierzchni ciała. Pacjenci z większym stopniem zajęcia skóry byli wyłączeni z badania.

\section{WNIOSKI}

Leczenie obejmujące codzienne stosowanie emolientów i doustną suplementację kwasami omega-3 zmniejsza nasilenie łuszczycy plackowatej u większości pacjentów, a przy tym właściwie nie wywołuje działań niepożądanych. U pacjentów z łuszczycą po zakończeniu leczenia stwierdza się zmniejszenie PASI, nasilenia rumienia, nacieku i łuski oraz powierzchni zmian skórnych. Ponieważ terapia właściwie nie wywołuje działań niepożądanych, może być przydatna jako leczenie wspomagające u chorych na łuszczycę. Umożliwia 
acids and the effect of the treatment on different types of psoriasis and varying severity of the disease.

\section{CONFLICT OF INTEREST}

The authors declare no conflict of interest zmniejszenie dawek leków i czasu trwania konwencjonalnej terapii tej choroby, a tym samym ogranicza działania niepożądane. Niezbędne są dalsze badania, aby określić optymalną dawkę kwasów omega-3 oraz skuteczność opisanego leczenia w poszczególnych typach łuszczycy o różnym nasileniu.

\section{KONFLIKT INTERESÓW}

Autorzy deklarują brak konfliktu interesów.

\section{References}

Piśmiennictwo

1. Griffiths C., Barker J.N.: Psoriasis. [in:] Rook's textbook of dermatology. $8^{\text {th }}$ ed. T. Burns, S. Brethnach, N. Cox, C. Griffiths (eds.). Blackwell Publishing, West Sussex, 2010, 1-22.

2. Gudjonsson J.E., Elder J.T.: Psoriasis. [in:] Fitzpatrick's dermatology in general medicine. $8^{\text {th }}$ ed. L.A. Goldsmith, S.I. Katz, B.A. Gilchrest, A.S. Paller, D.J. Leffel, K. Wolff (eds.). McGraw Hill, New York, 2012, 197-224.

3. Kagami S., Rizzo H.L., Lee J.J., Koguchi Y., Blauvelt A.: Circulating Th17, Th22, and Th1 cells are increased in psoriasis. J Invest Dermatol 2010, 130, 1373-1383.

4. Love T.J., Qureshi A.A., Karlson E.W., Gelfand J.M., Choi H.K.: Prevalence of the metabolic syndrome in psoriasis: results from the National Health and Nutrition Examination Survey, 2003-2006. Arch Dermatol 2011, 147, 419-424.

5. Cakmur H., Dervis E.: The relationship between quality of life and the severity of psoriasis in Turkey. Eur J Dermatol 2015, 25, 169-176.

6. Traub M., Marshall K.: Psoriasis - pathophysiology, conventional and alternative approaches to treatment. Alt Med Rev 2007, 12, 319-330.

7. Laddha G.P., Vidyasagar G., Bavaskar S.R., Bhole N.: Omega-3 fatty acid: living longer happier from complexities. Int J Pharm Bio Sci 2012, 2, 60-75.

8. Calder P.C.: Polyunsaturated fatty acids and inflammatory processes: new twists in an old tale. Biochimie 2009, 91, 791-795.

9. van Onselen J.: An overview of psoriasis and the role of emollient therapy. Br J Community Nurs 2013, 18, 174-179.

10. Guida B., Napoleone A., Trio R., Nastasi A., Balato N., Laccetti R., et al.: Energy restricted, n-3 polyunsaturated fatty acids-rich diet improves the clinical response to immuno-modulating drugs in obese patients with plaque-type psoriasis: a randomized control clinical trial. Clin Nutr 2014, 33, 399-405.

11. Mari N.L., Simao A.M.C., Dichi I.: n-3 polyunsaturated fatty acids supplementation in psoriasis: a review. Nutrire 2017, $42,5$.

12. Escobar S.O., Achenbach R., Iannantuono R., Torem V.: Topical fish oil in psoriasis - a controlled and blind study. Clin Exp Dermatol 1992, 17, 159-162.

13. Soyland E., Funk J., Rajka G., Sandberg M., Thune P., Rustad L., et al.: Effect of dietary supplementation with very long chain n-3 fatty acids in patients with psoriasis. N Eng J Med 1993, 328, 1812-1816.

14. Grimminger F., Mayser P., Papavassilis C., Thomas M., Schlotzer E., Heuer K.U., et al.: A double-blind, randomized, placebo-controlled trial of n-3 fatty acid based lipid infusion in acute, extended guttate psoriasis. Rapid improvement of clinical manifestations and changes in neutrophil leukotriene profile. Clin Invest 1993, 71, 634-643.

15. Mayser P., Mrowietz U., Arenberger P., Bartak P., Buchvald J., Christophers E., et al.: Omega-3 fatty acid-based lipid infusion in patients with chronic plaque psoriasis: results of a double-blind, randomized, placebo-controlled, multicenter trial. J Am Acad Dermatol 1998, 38, 539-547.

16. Mayser P., Grimm H., Grimminger F.: N-3 fatty acids in psoriasis. Br J Nutr 2002, 87 Suppl 1, 77-82.

17. Zulfakar M.H., Edwards M., Heard C.M.: Is there a role for topically delivered eicosapentaenoic acid in the treatment of psoriasis? Eur J Dermatol 2007, 17, 284-291.

18. Balbás G.M., Regana M.S., Millet P.U.: Study on the use of omega-3 fatty acids as a therapeutic supplement in treatment of psoriasis. Clin Cosmet Investig Dermatol 2011, 4, 73-77.

19. Assessing a psoriasis patient. [in:] Psoriasis and psoriatic arthritis pocket guide: treatment algorithms and management guide. $3^{\text {rd }}$ ed. A.V. Voorhees, S.R. Feldman, J.Y.M. Koo, M.G. Lebwohl, A. Menter A (eds.). National Psoriasis Foundation, Portland, 2009, 9-44.

20. Puzenat E., Bronsard V., Prey S., Gourraud P.A., Aractingi S., Bagot M., et al.: What are the best outcome measures for assessing plaque psoriasis severity? A systematic review of the literature. J Eur Acad Dermatol Venereol 2010, 24, 10-16.

21. Carlin C.S., Feldman S.R., Kreuger J.G., Menter A., Krueger G.G.: A 50\% reduction in the Psoriasis Area and Severity Index (PASI 50) is a clinically significant endpoint in the assessment of psoriasis. J Am Acad Dermatol 2004, 50, 859-866.

22. Kurd S.K., Gelfand J.M.: The prevalence of previously diagnosed and undiagnosed psoriasis in US adults: results from NHANES 2003-2004. J Am Acad Dermatol 2009, 60, 218-224.

23. Dogra S., Yadav S.: Psoriasis in India: prevalence and pattern. Indian J Dermatol Venereol Leprol 2010, 76, 595-601.

24. Mabuchi T., Ota T., Manabe Y., Ikoma N., Ozawa A., Terui T., et al.: HLA-C*12:02 is a susceptibility factor in late-onset type of psoriasis in Japanese. J Dermatol 2014, 41, 697-704.

25. Puri N., Mahajan B.B., Sandhu S.K.: Clinical evaluation of different therapeutic modalities in psoriasis by PASI score. Our Dermatol Online 2013, 4, 16-22.

26. Arican O., Aral M., Sasmaz S., Ciragil P.: Serum levels of TNF-alpha, IFN- gamma, IL-6, IL-8, IL-12, IL-17 and IL-18 in patients with active psoriasis and correlation with disease severity. Mediators Inflamm 2005, 24, 273-279. 
27. Lassus A., Dahlgren A.L., Halpern M.J., Santalahti J., Happonen H.P.: Effects of dietary supplementation with polyunsaturated ethyl ester lipids (Angiosan) in patients with psoriasis and psoriatic arthritis. J Int Med Res 1990, 18, 68-73.

28. Bittner S.B., Cartwright I., Tucker W.F., Bleehen S.S.: A double blind randomized placebo controlled trial of fish oil in psoriasis. Lancet 1988, 20, 378-380.

29. Gupta A.K., Ellis C.N., Tellner D.C., Anderson T.F., Voorhees J.J.: Double blind placebo controlled study to evaluate the efficacy of fish oil and low dose UVB in the treatment of psoriasis. Br J Dermatol 1989, 120, 801-807.

30. Kragballe K., Fogh K.: A low-fat diet supplemented with dietary fish oil results in improvement of psoriasis and in formation of leukotriene B5. Acta Derm Venerol 1989, 69, 23-28.

31. Rahman M., Beg S., Anwar F., Kumar V.: [in:] Omega-3 fatty acids. Beneficial effect of long chain omega-3 fatty acids in psoriasis. M.V. Hodge, A.V. Zanwar, S.P. Adekar (eds.). Springer, 2016, 531-540.

32. Upala S., Yong W.C., Theparee T., Sanguankeo A.: Effect of omega-3 fatty acids on disease severity in patients with psoriasis: a systematic review. Int J Rheum Dis 2017, 20, 442-450.

33. Gupta A.K., Ellis C.N., Goldfarb M.T.: The role of fish oils in psoriasis: a randomized double blind placebo controlled study to evaluate the effect of fish oils and topical corticosteroid therapy in psoriasis. Int J Dermatol 1990, 29, 591-597.

34. Henneicke-von Zepelin H.H., Mrowietz U., Färber L., Bruck-Borchers K., Schober C., Huber J., et al.: Highly purified omega-3-polyunsaturated fatty acids for topical treatment of psoriasis. Results of a double-blind, placebo-controlled multicenter study. Br J Dermatol 1993, 129, 713-717.

Received: 28.03.2017

Accepted: 9.05 .2017

Otrzymano: $28.03 .2017 \mathrm{r}$.

Zaakceptowano: $9.05 .2017 \mathrm{r}$.

How to cite this article

Adil M., Singh P.K., Maheshwari K.: Clinical evaluation of omega-3 fatty acids in psoriasis. Dermatol Rev/Przegl Dermatol 2017, 104, 314-323. DOI: https://doi.org/10.5114/dr.2017.68778. 